\title{
THE REGULATION OF MANAGEMENT INVESTMENT TRUSTS FOR THE PROTECTION OF INVESTORS
}

Sectiox 30 of the Public Utility Holding Company . Ict of 1935 authorized the Securities and Exchange Commission to investigate investment trusts and report its findings and recommendations to Congress. ${ }^{1}$ After more than a year of study, the Chairman of the Conmission stated in a letter transmitting the preliminary report to Congress that the Commission was convinced of a need for comprehensive legislation to protect investors and to prevent socially undesirable control of other corporations by investment trusts. ${ }^{2}$ In the light of the probabilities of such legislation, this comment will discuss that phase of the problem which concerns the protection of investors.

The name investment trust has been used loosely to designate many types of organizations formed for the purpose of investing funds of numerous participants in a diversified group of securities. The term originated in England in the middle of the 19th century when the first investment trusts were organized as common law trusts. ${ }^{3}$ Subsequent to the passage of the Companies Act in 1862, British investment trusts were generally organized as limited companies. After the financial depression during the 1890 's, these investment trusts have, for the most part, been conservatively and successfully operated with no regulation other than by the Companies Act.5 There are now orer two hundred companies with a combined capital of some three luundred million pounds. ${ }^{6}$ Typically, the British company has a capital structure of jumior and senior securities. The proceeds of the sale of these securi-

1. 49 STAT. 837 (1935), 15 U. S. C. $\$ 79 z-4$ (Supp. 1936). "The commission is authorized and directed to make a study of the functions and activitics of investment tr usts and investment companies, the corporate structures, and investment policies of such trusts and companies, the influence exerted by such trusts and companies upon companies in which they are interested, and the influence exerted by interests affiliated with the management of such trusts and companies upon their investment policies and to report the results of its study and its recommendations to the Congress on or before January 4, 1937."

2. S. E. C., Preliminary Summary of the Progress of the Study of Investment Trusts and Investment Companies (Jan. 8, 1937) ii. The scope of the study is broad and inclusive. The information and material used in the study have been prepared through the medium of specially prepared questionnaires, preliminary discussions and conferences with representatives of investment trusts, field studies and public examinations.

3. See generally Sykes v. Beadon, $11 \mathrm{Cl}$. D. 170 (1879); Smith v. Anderson, 15 Ch. D. 247 (1880); Robinson, Investatent Trust Onganization ando Aln:ingessent (rev. ed. 1929) 9. The genesis of the British investment trusts seems to have occurred in Belgium in 1822. Graysox, Investament Trusts (192S) 11.

4. Grayson, Investarent Trusts (1928) 22 .

5. Durst, Analysis and Handeook of Investarent Trusts (1932) 7; Grayson, INTESTMIENT TRUSTS (1928) $15,31$.

6. Investment Trust Groups, (Sept. 26, 1936) 124 TuE Ecososisr 567. 
ties are invested in a widely diversified portfolio of bonds, preferred stocks and common stocks. The management, for reasonable compensation, continuously supervises the portfolio and has complete control of the investments. Ultra conservative accounting methods are used so that large reserves, both apparent and hidden, are kept as a safeguard against periods of business depression. ${ }^{7}$

In contrast to the slow, conservative, and stereotyped growth of investment trusts in Great Britain, their rise in this country has been recent, meteoric, and confused. From insignificance before $1924,{ }^{8}$ the movement recruited hundreds of organizations controlling assets estimated at more than six and a half billion dollars before the market crash in 1929,0 with more than half of the growth taking place after $1927 . .^{10}$ This phenomenal development which made investment trusts almost as large in size as building and loan associations, ${ }^{11}$ over a third as large as life insurance companies ${ }^{12}$ and over a half as large as savings banks ${ }^{13}$ as investors of the public's money, was due not only to the avid desire of the public for securities in the boom era ${ }^{14}$ but also to an apparently genuine demand for the distribution of risk and skilled management not otherwise available to the small investor. ${ }^{16}$

This comment will be concerned primarily with the "management type" trusts $^{16}$ which form about $70 \%$ in number and probably even a greater percentage in amount of assets of the investment trusts in this country. These are generally private corporations following to some extent the conventional British plan. ${ }^{17}$ The capital structure usually consists of junior and senior equities and, less often, debentures. ${ }^{18} \mathrm{~A}$ great many are sponsored by invest-

7. Robinson, op. cit. supra note 3, at 7; OtTINGER ANd SBEA, A SURvey of THE Activities and Forms of Investment Trusts with Recommendations for Statutory Regulation by the New York State Department of Law (1927) 6.

8. S. E. C., op. cit. supra note 2 , at 7.

9. S. E. C., op. cit. supra note 2, at 7. Cf. Keane, Manual of Investment Trusts (1932) $\mathrm{ii}$.

10. In 1928 and 1929 at least $\$ 2,500,000,000$ worth of investment trusts securities were issued. KEANE, loc. cit. supra note 9. About a quarter of the corporate financing in the United States in 1929 was done by investment trusts and holding companies. STAtistical Abstract of the United States (U. S. Dep't Commerce 1936) 293.

11. Statistical Abstract of the United States (U. S. Dep't of Commerce, 1936) 257.

12. Id. at 282.

13. Id. at 243. One banker claimed that savings banks had lost about a billion dollars of potential deposits because of the rise of investment trusts, N. Y. Times, Mar. 24, 1928. p. 23, col. 1.

14. See N. Y. Times, Oct. 16, 1929, p. 9, col. 2.

15. Rosinson, op. cit. supra note 3 , at 3 .

16. S. E. C., op. cit. supra note 2 , at 7.

17. Some are organized as business trusts. OTTINGER AND SHEA, op. cit. supra note 7 , at 19.

18. Shaviro, The Regulation of Investment Trusts: What the S.E.C. Will Probably Recommend (1936) 48 A ANalist 454. The issuance of debentures by British in- 
ment banking firms, brokerage houses, and other financial institutions. ${ }^{10}$ The majority are formed for the ostensible purpose of investing funds in a widely diversified portfolio of securities and grant unlimited powers to their directors in the control of the portfolio.. ${ }^{20}$ Some, however, have been formed to invest in a single industry ${ }^{21}$ or to profit by trading in securities rather than by conservative investing. ${ }^{22}$ Other enterprises, nominally investment trusts, operate as holding companies ${ }^{23}$ - the uncertain distinction between investment trusts and holding companies depending upon whether the purchasing of securities is for investment or managerial purposes. ${ }^{24}$ Another type of management investment trust is the "open end" or "mutual" trust which permits the holder at his option to redeem his security at the asset value minus a withdrawal charge. ${ }^{25}$ The only useful generalization that can be made concerning management investment trusts is that they include all investment companies which give their management a considerable discretion as to investment policy.

Lack of confidence in managerial capacity, particularly following the market crash, gave rise to what is known as the fixed or semi-fixed investment trusts $^{26}$ which constitute $25 \%$ of the total number. ${ }^{27}$ In these trusts the sponsor deposits with the trustee under a trust indenture a certain diversified group of securities called a unit. Against this unit the trustee issues participation certificates which the sponsor sells to the public. In the fixed trust the composition of the unit remains unchanged during the duration of the trust, but in the semi-fixed trust provisions for release and substitution in the indenture may give the sponsor either a limited or an almost complete managerial control..$^{28}$ The other 5\% of the total number of investment trusts consist of special investment plans involving installment payments.99

vestment trusts is practically universal. OtTINGer aND Snes, of. cit. supro note 7, at 20.

19. OtTINGER Axd SHEA, op. cit. supra note 7, at 10; Rodrssos, op. cit. suspra note 3 , at 21 .

20. Ottinger and Shes, op. cit. supra note 7, at 77.

21. Id. at 76 .

22. Id. at 79 .

23. Id. at 131; SEN. REP. No. 1455, $73 d$ Cong., 2d Sess. (1934) 360.

24. SEN. REp. op. cit. sipra note 23, at 363. Part of the purpose of the investigation of the Securities and Exchange Commission is to determine the control exercised by so-called investment trusts over the companies in which it holds stock. See note 1 sipra.

25. S. E. C., op. cit. supra note 2 , at 3.

26. Fixcd and Flcxible Trusts, A Suriey (Miar. 7, 1936, supp.) 122 TuE Eco:oxIST 1.

27. S. E. C., op. cit. supra note 2, at 7.

28. See generally Robnsow, op. cit. supra note 3, at 49 et seq.; Myers, Fired Investment Trusts-Soni Obseriations (1929) 4 Sr. Jontr's L. Rev. 1; Fired and Flexible Trusts, A Surcey (Mar. 7, 1936, supp.) 122 Tue Eco:tonist 1. The abuses of fixed trusts have led to proposals for regulation in England. The Fired Trust Refort (Aug. $15,1936) \geq 24$ THE Ecoxomist 311.

29. S. E. C., op. cit. supra note 2, at 7. 
In spite of warnings before the crash in 1929, investors were purchasing the securities of management investment trusts at prices which were far above the actual book values of the securities held by the trust as its assets. Since these were in turn based upon portfolios purchased at inflated prices, ${ }^{30}$ it is not surprising that holders of investment trust securities were among the chief sufferers in the deflation after 1929. When the boitom of the market was reached in 1932, the total assets (market value of the securities held by investment trusts) had shrumk from six and a half billion clollars to one and a half billion. ${ }^{31}$ This tremendous shrinkage was intensified by the abuses which had become prevalent during the rapicl and unrestrained growth of investment trusts. The prevalence of these abuses in the organization and administration of investment trusts will not be known in detail until the Securities and Exchange Commission has made its final report. While it is clear that many investment trusts have been, either completely or to a large extent, free from these malpractices, the eviclence alreacly available shows that in more than a few isolated cases the investment trust field has been a playground for incompetent and unscrupulous managers and promoters. The abuses which have arisen with respect to the management type of investment trust concern both the original promotion and subsequent management.

The most frequently condemned practice arising in the course of promotion is the taking of profits and control by the promotors grossly disproportionate to their contribution of capital. ${ }^{32}$ Another criticism has been directed at the breadth of the charter provisions which grant unlimited powers to management ${ }^{33}$ and seek to absolve the management from liability to stockholders. ${ }^{34}$ Investment trusts have also been criticized for inadequate dis-

30. In a report to the convention of the Investment Bankers Association such a warning was given. The report stated that: "It is possible that if such losses become widespread there will be renewed agitation for regulation by state and federal authorities." N. Y. Times, Oct. 16, 1929, p. 9, col. 2. In an editorial it was said that "no one in touch with the ideas of Wall St. can have missed the prevalent impression that the stock market's recent activities have been associated with the immensely increased resources of the investment trusts". N. Y. Times, Sept. 8, 1929, §3, p. 4, col. 2.

31. S. E. C. op. cit. supra note 2 , at 7.

32. This may be accomplished by the use of several classes of stock, option warrants, or management contracts. FlynN, Investment Trusts Gone Wrong! (1931) 33; SEN. REP. op. cit. supra note 23, at 339; Record, Public Examination of General American Investors Co., Inc., by the S. E. C. held in conjunction with the investment trust study (Nov. 12, 1936) 5730. Citations to this record will hereafter be referred to merely as the Record, followed by the name of the investment trust examined. This public examination has been reported almost daily by the N. Y. Times from the time the hearings commenced in July, 1936.

33. Record, Spencer Trask Fund, Inc. (Sept. 30, 1936) 3164.

34. Record, Spencer Trask Fund, Inc. (Sept. 30, 1936) 3150; Record, Liberty Share Corp. (Dec. 29, 1936) 8942. A similar clause is set out in SEN. REP. op. cit. supra note 23 , at 353 . "In case the corporation enters into contracts or transacts business with one 
closure of relevant facts to the investing public in the original sale of securities ${ }^{3-}$ and consequent confusion of the public as to the risks involved in the purchase of their securities. In general, investment trusts represent themselves to the public as semi-conservative investment mediums, almost never as agencies through which an investor can gamble on the skill or luck of the speculator-manager to whom he entrusts his funds; the advertising of many trusts has heen composed with the intent of conveying an impression of super-conservative investment skill, and all kinds of investment trusts from obviously speculative to ultra conservative investment companies have used the misleading and impressive label "investment trust." 38

Criticism of the management of investment trusts has been directed toward the lack of clisclosure to the investing public of earnings and investments, ${ }^{37}$ and misleading financial statements resulting from the lack of standard accounting methods. ${ }^{3 s}$ Other practices open to attack are the acquisition of highly speculative rather than dividend paying stocks, ${ }^{30}$ the excessive concentration of investments in one or a few companies ${ }^{40}$ - particularly for the purposes of control rather than investment, 11 excessive trading, speculating, 12 short selling, borrowing and lending money, 43 and the participation of in-

or more of its directors, or with any firm of which one or more of its directors are members, or with any other corporation or association of which one or more of its directors are stockholders, directors, or officers, such contract or transaction shall not be invalidated or in any wise affected by the fact that such director or directors doing it may have interests therein which are or might be adverse to the interests of this corporation, even though the vote of the director or directors having such adverse interest shall have been necessary to obligate the corporation upon such contract or transaction. No such director or directors shall be liable to the corporation, or to any stoclsholder or creditor thereof, or to any other person, for any loss incurred by it under or by reason of such contract or transaction, nor shall such director or directors be accountable for any gain or profits realized thereon."

35. Excerpt from Attorney General Bennett's report to the $\mathbb{R}$. Y. state legislature on Mar. 5, 1936. KenNe, Maxual of Investaest Trusts (1032) 1755.

36. In a report of the investment trust committee of the Investment Banlers' Association it was said: "The Committee are of the opinion that there has been a good deal of general misunderstanding which is no doubt due to a large extent to the title "investment trust' really a misnomer." N. Y. Times, July 3, 1928, p. 32, col. 2. See also OrrmGER AND SHeA, op. cit. supra note 7, at 8; Record, Mlayflower Associates, Inc (Oct. 13, 1936) 3690 .

37. Bennett, loc. cit. supra note 35 ; SEN. REP. op. cil. sulpra note 23, at 363; Record, Liberty Share Corp. (Dec. 29, 1936) 9000.

38. Record, Liberty Share Corp. (Dec 29, 1936) 9039.

39. SEN. REP. op. cit. supra note 23, at 348.

40. Sex. Rep. op. cit. supra note 23, at 348. Record, Petroleum Corp. of America (Sept. 28, 1936) 2856.

41. SEN. REP., op. cit. stipra note 23 , at 359.

42. Bennett, loc. cit. supra note 35; Record, Equity Corp. (Aug. 3, 1936) 934; Record, Liberty Share Corp. (Dec 29, 1936) 9027.

43. OtrIivger ANn SHEA, op. cit. supra note 7, at 21 ; Bennett, loc. cif. sufro note 35; Record, Liberty Share Corp. (Dec. 29, 1936) 8599. 
vestment trusts in the underwriting of new securities ${ }^{44}$ or in trading accounts. ${ }^{45}$ Perhaps, the most serious criticism, however, has involved the abuses by managers resulting from conflicts between their own interests and their duty toward the investors. The conflicts arise because investment trusts are often sponsored or controlled by banks, investment banking houses, brokerage concerns or other investment trusts. They are manifested in various ways: the participation of investment trusts in underwritings in which the controlling investment bank is interested $;^{40}$ the use of an investment trust as a dumping ground for unmarketable securities; ${ }^{47}$ the unneccessarily frequent substitution in the portfolio for the purpose of obtaining commissions for the brokerage house which controls it $;^{48}$ sales and purchases of securities to and from sponsors, officers, and directors; ${ }^{49}$ loans to officers and directors $;^{50}$ the control of one investment trust by another to permit transactions between the two resulting in injury to one. 51

A recent case will serve to illustrate the manner in which the interests of security holders in an investment trust may be abused. ${ }^{52}$ In 1928 a brokerage house, controlled and operated by two men, organized an investment trust. It was incorporated with an authorized capital of 32,000 shares of Class $A$ 7\% voting preferred stock with a par value of $\$ 25$ a share and 2,000 shares of Class B no par common stock with equal voting power per share. The common stock was immediately voted to the brokerage house as compensation for services in promoting the corporation. A resolution was then passed which gave the brokerage house a five-year option to purchase at $\$ 25.00$ per share all of the Class A stock and provided that the brokerage house was to be the sole selling agent of all the preferred stock upon which they did not exercise their option. By this arrangement the brokerage house was in a position to control the investment trust. A number of prominent

44. Record, Spencer Trask Fund, Inc. (Sept. 30, 1936) 3166; Record, Lehman Corp. (Nov. 10, 1936) 5554.

45. Record, Spencer Trask Fund, Inc. (Sept. 30, 1936) 3173; Liberty Share Corp. (Dec. 29, 1936) 8900.

46. See, e.g., Record, Lehman Corp. (Nov. 10, 1936) 5554.

47. Bennett, loc. cit. supra note 35; SEN. REP., op. cit. supra note 23, at 351 ; FLYNN, op. cit. supra note 32, at 52; Record, Prince \& Whitely Trading Corp. (Jan. 7, 1937) 9477.

48. SEN. REP., op. cit. supra note 23, at 362 .

49. Record, Liberty Share Corp. (Dec. 30, 1936) 9144.

50. Bennett, loc. cit. supra note 35; Record, Liberty Share Corp. (Dec. 29, 1936) 8905.

51. Record, Equity Corp. (July 31, 1936) 839. The abuses are similar to those which arose in connection with public utility holding companies such as pyramiding and intercompany manipulations. See Comment (1936) 45 Y ALE L. J. 468, 474. Certain socalled investment trusts are within the scope of the Public Utility Holding Company Act of 1935. 49 StaT. 804 (1935), 15 U. S. C., \$ 79b (Supp. 1936).

52. O'Connor v. First Nat. Investors' Corporation of Virginia, 163 Va. 908, 177 S. E. 852 (1935). 
men were elected as directors. On the strength of their names 4,000 shares of the preferred stock were sold to the public at $\$ 25.00$ a share. The board of directors was inactive and the trust was operated by the brokerage house which had, therefore, complete control of $\$ 100,000$ of the investors' money without having contributed any cash whatsoever. The brokerage house thus had everything to win, both through the option on the preferred stock and ownership of the common, for the brokerage house could either gamble with the assets or employ them in its own business. On the other hand, it had little to lose should the enterprise prove unsuccessful. From its formation until July, 1931, when persistent rumors of the financial difficulties of the brokerage house led to an investigation, the operations of the trust were unknown even to most of the directors. The investigation disclosed, among other instances of gross mismanagement, that the brokerage house had sold over-valued and even worthless stock to the investment trust; that the brokerage house had borrowed money and securities from the investment trust without authorization; and that the value of its assets was reduced from $\$ 100,000$ to $\$ 20,000.53$

Such losses to investors after 1929, caused in part by the abuses disclosed, have already resulted in a limited amount of public control and in demand for more extensive regulation. As early as 1927 it was recognized that investment trusts, often represented as conservative and responsible investment institutions, were proper subjects for stricter regulation than ordinary commercial and industrial corporations, ${ }^{54}$ since they are entrusted with the responsibility of investing other people's money in securities which are easily transferable, and hence offer large temptations to unscrupulous managers..$^{\text {t5 }}$ Before discussing the existing regulation and problems arising from proposals for further control, it will be necessary to consider separately two broad categories of such regulation. The first is regulation by means of publicity, the theory underlying the Securities Act and the Securities Exchange Act; the second is more affirmative regulation by supervision of the actual management of the trusts.

There is general agreement, even among the investment trusts themselves, that full disclosure of the promotion and management of investment trusts would be desirable.56 Such publicity has already been accomplished to a

53. The court held that the "dummy" directors were liable to stodtholders for breach of the fiduciary duty. O'Connor v. First Nat. Investors' Corporation of Virginia, 163 Va. 908,177 S. E. 852 (1935).

54. "The history of all State regulation shows that there is a tendency on the part of the people to permit individual enterprise to flourish until some great public evil or catastrophe occurs and then restrictive and drastic legislation is made efiective, locling the barn door after the horse has been stolen." Ottraver And SHen, op. cit. supra note 7 , at 100 .

55. See Goodwin v. Simpson, 197 N. E. 628, 630 (1fass. 1935); O'Connor v. First Nat. Investors' Corporation of Virginia, 163 Va. 908, 926, 177 S. E. 852, 860 (1935).

56. Among those who have recommended such legislation are: Otto $\mathrm{H}$. Kahn, SEx. REP., op. cit. supra note 23, at 363; Paul C. Cabot, Record, State Street Investment 
considerable extent, particularly with reference to the original sale of secturities to the public. The Federal Securities Act ${ }^{57}$ is of course the most farreaching means of forcing full disclosure of the organization and promotion of investment trusts in the original sale of securities to the public. While no specialized form for information has yet been adopted, ${ }^{, 8}$ a study of registration statements, which were ineffective because of withdrawal, refusal, or stop orders, disclosed such abuses as pyramiding, exorbitant profits and control to promoters, conflicting interests and unreliability of the sponsors. ${ }^{.00}$ Also, a number of states have adopted, in the form of Blue-Sky law rules and regulations, ${ }^{60}$ the recommendations of the National Association of Securities Commissioners concerning special information necessary for investors in investment trusts. ${ }^{\text {in }}$ This information includes the number of shares of each class of stock held by directors and officers and the casl consideration paid for stuch shares; the class of stock having voting power and the names of those who own and control it; financial statements and the contents of the portfolio classified by kinds of securities, industries, and countries; the connection of the investment trust to its investment house or banking institution and the circumstances under which these latter institutions may deal with the investment trust; the transactions between the investment trust and officers and directors; the policies of investment and of supplying information to its stockholders. At least two states require detailed evidence of the character and competency of the management and a conficlential disclosure of the complete contents of the portfolio. Finally, special information is required by the New York Stock Exchange as a prerequisite to the original listing of securities of investment trusts. relationship of the management to other institutions, operating experience, organization expenses, loans, commissions, non-roting stock. financial statements and portfolio.

It would seem, therefore, that information concerning the original promotion and organization has been made readily available to investors. Most of the conspicuous abuses have occurred, howerer, in the subsequent operation

Corp. of Boston (Sept. 23, 1936) 2784; H. M. Minton, Record, Spencer Trask Fund, Inc. (Sept. 30, 1936) 3205; R. D. McGrath, Record, General American Investors Co. (Nov. 12, 1936) 5842; Robert Lehman, Record, Lehman Corp. (Nov. 10, 1936) 5652; L. W. Schmidt, Record, Administrative and Research Corp. (Jan. 28, 1937) 11418.

57. 48 StAT. 74 (1933), 15 U. S. C. $\$ 77$ a (1934).

58. 131 C. C. H. Stocks and Bonds Law Serv. (1936) $₫ 2621$.

59. Cale, A Study of Incffective Inzestment Trusts and Precions Mctal Mining Issues (1937) 4 LAW and Contemporary Problems 32, 37.

60. 131 C. C. H. Stocks and Bonds Law Serv. (1936) Maine, 1785; Missouri, 2395; New Hampshire, 2777; New Mexico, 2975; North Dakota, 3282; Oklahoma, 3483; Vermont, 4380; West Virginia, 4684.

61. Robinson, op. cit. stupra note 3 , at 572 .

62. New York Stock Exchange special requirement for listing investment trust securities approved by committee on stock list, June 6, 1929, as amended to April, 1931. 
and management of the investment trust, matters on which the investor has been most completely uninformed, for state Blue-Sky laws and the Federal Securities Act are limited in their operation to the original distribution of securities. Except where the investment trust is classified as a financial institution and is therefore subject to periodic examinations by state officials and forced to make frequent disclosure to stockholders, ${ }^{13}$ no special requirements for disclosure under state laws exist. But under the Federal Securities Exchange Act of $1934,{ }^{6 *}$ the Commission can compel all investment trusts seeking registration on national security exchanges not only to make original

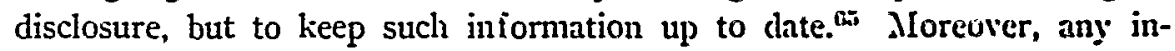
vestment trust not listed on a security exchange which nevertheless seeks registration under the Securities Act of 1933 must agree to furnish such subsequent periodic information. ${ }^{60}$ Special forms have been adopted by the Commission for investment trusts including not only detailed financial statement but information as to management and control, policies, remuneration, and sales of securities. ${ }^{\mathrm{ct}}$ The New York Stock Exchange requires, as consideration for listing privileges, an agreement that investment trusts will furnish their stockholders as well as the Stock Exchange with periodic financial statements and other relevant information. ${ }^{68}$ On the score of disclosure, therefore, it seems clear that machinery already exists for publicizing the affairs of large interstate investment trusts, although additional affirmative action by the states is probably necessary to compel disclosure in the case of small intrastate companies. In both cases more detailed and more frequent reports will be required, however, to satisfy the policy of regulation by disclosure.

Although there is little dissent from a belief in the desirability and the practicability of forcing adequate disclosure of information about the organization and management of investment trusts, there is a wide diversity of opinion on the feasibility of undertaking active supervision of their management, either directly or by the enactment of rules and standards of conduct for the varied types of investment trusts. The question of whether there is need for such regulation in addition to publicity, presents a difficult problem, the answer to which will depend on how legislative authorities

63. Michigan, under rule 4 of the Securities Department, requires that all management investment trusts qualify as finance companies. They are thus subject to special control. 131 C. C. H. Stocks and Bonds Law Serv. (1936) 2051 : Micn. Co:sr. Luws (1929) $\$ \$ 12181-12197$. A similar statute in Wisconsin was held not applieable to management investment trusts. Wisconsin Inv. Co. v. Skinner, 265 N. W. 681 (Wis. 1936).

64. 48 SтAт. $\$ 92$ (1934), 15 U. S. C. \$78e (1934).

65. 4 S St.1T. 894 (1934), 15 U. S. C. $\$ 78 \mathrm{~m}$ (1934).

66. 48 Stat. 895 (1934), 15 U. S. C. $\$ 780$ (1934), as amended 49 Star. 1377 (1936), 15 U. S. C. \$78o (Supp. 1936).

67. 135 C. C. H. Stocks and Bonds Law Serv. (1936) \6892.

68. Specjal agreements for investment trusts, New York Stock Exchange. Sce also Statement on Investment Trusts by committee on stock list (1931). 
assess the position of investment trusts in the financial system and the choice they make as to the direction in which the development of such organizations should be guided. The choice lies between two points of view. The first regards investors as sufficiently protected if they are informed of the management's financial interests in the concern; the second views investment trusts as so much like banking firms in function and so open to managerial abuse when unregulated as to require a measure of detailed supervision, by statutory rule and perhaps by inspection, comparable to the regulation of the investment policy of banks and insurance companies. Disclosure alone could hardly prevent managers from retaining an unreasonably large share of control and the right to future profits. Charter powers could still be unlimited and exculpatory clauses extensive. Moreover, subsequent disclosure of management disloyalty is small consolation to stockholders who have no means of holding such managers to the standard of fiduciaries. While it is true that the frequency with which this standard has been disregarded is partly due to the cloak of secrecy surrounding managerial conduct, ${ }^{69}$ reasons inherent in the structural organization of the business tend to permit managers to act disloyally with impunity.

Practically the sole means of enforcing the fiduciary standard has been the stockholders' representative suit. ${ }^{70}$ While courts have recently stated that managers of investment trusts would be held to higher standards than those of commercial, private, or industrial corporations, ${ }^{71}$ the difficulties connected with a stockholders' suit are numerous, even when stockholders have full knowledge of the facts. Stockholders are widely scattered and unorganized ;2 $^{72}$ litigation is expensive, and even if the defendants are solvent, satisfaction may be of doubtful value $;^{73}$ procedural difficulties, ${ }^{74}$ ingenuity of the managers, and uncertainty as to the unlawful kinds of misconduct also stand in the way. ${ }^{75}$ The result, therefore, may be that publicity alone will not assure that investment trusts will be operated solely for the benefit of stockholders.70 Furthermore, as long as charter powers are unlimited and shareholders are without control, publicity does not prevent the investment trust from being

69. See generally O'Connor v. First Nat. Investors' Corporation of Virginia, $163 \mathrm{Va}$. 908, 177 S. E. 852 (1935).

70. Dodd, Is Effective Enforcement of the Fiduciary Duties of Corporate Managers Practical? (1935) 2 U. OF CHI. L. REv. 194.

71. Goodwin v. Simpson, 197 N. E. 628 (Mass. 1935); O'Connor v. First Nat. Investors' Corporation of Virginia, 163 Va. 908, 177 S. E. 852 (1935).

72. See Dresdner v. Goldman Sachs Trading Corp., 240 App. Div. 242, 245, 269 N. Y. Supp. 360, 364 (2d Dep't 1934).

73. In Karasik v. Pacific Eastern Corporation, 180 Atl. 604 (Del. Ch. 1935), the court upheld the settlement of $\$ 300,000$, mostly in stock of the corporation itself, of the $\$ 1,000,000$ suit against the directors of the Goldman Sachs Trading Corporation.

74. Gerith Realty Corporation v. Normandie Nat. Securities Corp., 154 Misc. 615, 276 N. Y. Supp. 655 (Sup. Ct. 1933).

75. Dodd, loc. cit. supra note 70.

76. Douglas, Directors Who Do Not Direct (1934) 47 HARv. L. Rev. 1305, 1324. 
used for purposes other than the investment of funds. Its assets can be used for speculation, to control other enterprises, or for other purposes which, although within charter powers, are contrary to the original purposes held out to induce investment by the public. ${ }^{77}$ Finally, publicity in itself does not prevent the failure of an investment trust any more than bank examinations prevent insolvencies of banks. Nevertheless, adequate information in the hands of enlightened and litigious investors or their competent advisers might have a powerful indirect effect, and many investment trust managers feel that this alone would control the abuses. ${ }^{78}$ Without a test during a complete business cycle, it seems impossible to judge in advance the effectiveness of publicity as regulation; whether disclosure should be regarded as enough will be one of the most difficult decisions involved in framing future legislation.

Possible regulation in addition to enforced disclosure should have two aims. It should provide that the operation of the investment trust will be strictly for the benefit of those shareholders who supply the funds. Secondly, it should attempt to minimize the chance of failure and consequent loss to investors. Regulation for the first purpose can be accomplished in several ways. The most drastic and perhaps most promising statutory rule would be a prohibition against non-voting stock, stock of more than one class, and compensation to promoters in the form of stock. ${ }^{70}$ By these three prohibitions theoretical control would be left in the hands of those who contribute the capital and not in the hands of managers, who, holding a limited stake in the enterprise, might find it more profitable to deal with the assets for their own personal benefit against the best interests of the contributors of the capital. Existing legislation along this line seems to be limited to the provisions in two state Blue-Sky regulations prohibiting promotion stock-89 Legislation would be relatively ineffective unless all three prohibitions were combined. For example, promoters could purchase the entire issue of no par voting common stock for a nominal consideration and issue non voting preferred stock to the public. ${ }^{31}$ In this way, with a limited contribution promoters could control the investment trust.

The disadvantages of such legislation would lie in the necessity for reorganizing the capital structure of existing trusts and, more important, a prohibition against the use of preferred stocks. The purpose of preferred stock in investment trusts has been twofold: to offer to the public a security

77. In People v. Latta, 137 Misc. 208, 244 N. Y. Supp. 487 (Sup. Ct. 1930) an injunction was granted under the Martin Act partly because of the failure of the investment trust to carry out its advertised purposes.

78. See note 56, supra.

79. Shaviro, loc. cit. supra note 18.

80. Alabama and California 131 C. C. H. Stocks and Bonds Law Serv. (1936) 163, 465.

S1. This was done in People v. Latta, 137 Mísc. 20\&, 244 N. Y. Supp. 487 (Sup. Ct. 1930). 
of limited risk and to make the conmon stock more attractive through the possibility of increasing its earning and licquidating value by means of the leverage afforded to the common shares. ${ }^{82}$ Thus managers holding a substantial investment in common stock have the incentive, because of the leverage, to promote the best interests of the trust, for a substantial increase in earnings and asset value will inure to their benefit: conversely a substantial decline will in the first instance adversely affect the common stock. ${ }^{83}$ A possible means of preventing control from falling to those without a substantial investment in the enterprise and at the same time permitting the use of preferred stock might be to limit the conmon stock to par value equal to that of voting preferred. In this way majority control and majority investment would go along together, and it would be more difficult for the management, holding one class of securities, to have an interest as security holders in conflict with the interests of the mass of investors in the trust.

Even where there is a concurrence of financial contribution and control such as might be required by this kind of regulation of capital structures, it seems reasonable to contemplate a clash of interest between management and the security holders at large based not on the management's control of a special class of security, but on the availability to it, as management, of other sources of special profit. In view of this diversity of intcrest between management and investors, a statute regulating investment trusts might treat shareholders of investment trusts not simply as co-owners of the enterprise but in the same category as depositors in sarings banks or policy holders in life insurance companies. Provision might then be made for means other than stockholder's suits to enforce fiduciary duty on the part of managers. Such legislation might prohibit purchases and sales of sectrities and loans of cash or securities between managers and the investment trust in the same way that transactions between banks and their executive officers are regulated by the Federal Reserve $\mathrm{Act}^{84}$ and the Banking Act of $1933 .{ }^{85}$ Michigan, whose Blue-Sky regulations qualify investment trusts as finance companies, prohibits such transactions between managers and the investment trust. ${ }^{86}$ Legislation of this type would of course render invalid broad provisions absolving managers from liability for breach of their fiduciary duty, although it is questionable whether such exculpatory clauses are legally operative even in the absence of legislation. ${ }^{87}$

Other proposed legislation, addressed to the problems presented by the divorce of ownership and control, implicit in the investment trust device,

82. Montgomery, Financial Handbook (2d ed. 1933) 1245.

83. Record, United States and Foreign Securities Corp. (Feb. 12, 1937) 11722.

84. 38 Stat. 272 (1913), 12 U. S. C. $\$ 375$ (1934).

85. 48 StAт. 182 (1933), 12 U. S. C. §375a (1934).

86. See note 63 , supra.

87. See Whalen v. Hudson Hotel Co., 183 App. Div. 316, 320, 170 N. Y. Supp. 855, 858 (3d Dep't 1918). 
would go further in enforcing fiduciary duties upon management by preventing situations out of which arise temptations to operate the trust for personal benefit. This legislation would segregate investment trust management from investment banking firms, brokerage houses and other affiliations on the theory that a combination of these functions gives rise to conflicts of interest which are likely to be resolved against the trust. ${ }^{83}$ Regulation of this type is similar to the segregation of commercial banks from investment affiliates under the Banking Act of $1933,{ }^{89}$ and to the proposed segregation of brokers and dealers under the Securities Exchange Act of 1934.00 Segregation is a drastic remedy, and recently the Securities and Exclange Commission refrained from recommending the segregation of brokers and dealers on the ground that it was not feasible at the moment. ${ }^{\text {I }}$ Segregation in the case of investment trusts should be employed with equal caution, ${ }^{92}$ and the question of whether it is necessary at all is one of the key problems of policy facing the framers of a statute. When provision was made for the segregation of banks from investment affiliates in the Banking Act of 1933, the affiliates had not been subjected to examination or regulation by either federal or state authorities, and affiliates were so generally unpopular that the discussion turned on how the divorce should be effected rather than its desirability. ${ }^{93}$ Comparable conditions of scandal and abuse bear on the problem of segregating investment trusts from investment banking firms and brokerage houses.

The segregation of financial functions is justifiable only when these functions are in substantial conflict. The selling of securities by investment bankers does conflict with careful and unbiased purchasing of securities by investment trusts controlled by those bankers. However, there are other functions of both investment trusts and investment banks which are parallel, and in these the relationship of the banking house to the investment trust would appear to be valuable. For example, investment banks furnish long experience in handling substantial amounts of capital; they provide practical experience in appraising companies and industries; and they can supply to the investment trusts useful information which they obtain from their industrial and financial associations. ${ }^{34}$ Brokerage houses may supply some of the services of investment banks but their aid is limited, since their necessary concentration on brokerage fees must inevitably conflict with the function

88. Shaviro, loc. cit. supra note 18.

89. 48 Stat. 188 (1933), 12 U. S. C. \$ 377 (1934).

90. 48 Stat. 891 (1934), 15 U. S. C. $\$ 78 k$ (1934).

91. Securities and Exchange Conanission, Reront on tae Fensidiluti aid Adtisabitity of the Coarplete Segregation of the Functions of Deales alid Brofers (1936).

92. Record, General American Investors Co. (Nov. 12, 1936) 5344.

93. Westerfield, The Banking Act of 1933 (1933) 41 J. of PoL. Ecos. 721, 739.

94. See statement of Mr. Lehman, Record, Leliman Curp. (Nov. 10, 1936) 564 . 
of investment trusts of disinterested shifting of investments. As a solution, ${ }^{05}$ the New York Stock Exchange has recommended independent directors for investment trusts controlled by banking houses. Perhaps definite prohibitions against transactions between investment trusts and their financial affiliates might be justified. But it would seem questionable whether wholesale segregation is either feasible or desirable, particularly without consideration of the efficacy of publicity and other less drastic regulation.

Another type of regulation assumes that control and ownership are separated, and would indirectly give control to the suppliers of funds by making all trusts open-end so as to provide for all shareholders the right to redeem their stock and receive a pro rata share of assets at any time. ${ }^{90}$ The Revenue Act of 1936 is designed to induce investment trusts to mutualize and grant these redemptive privileges by allowing certain exemptions from taxation to trusts of this type. ${ }^{9 i}$ Mutualization would necessitate the reorganization of existing trusts and place a limitation on the use of securities of more than one class. ${ }^{98}$ Senior securities could not be used unless some arrangement were devised whereby junior security holders could redeem and at the same time have sufficient senior securities called to maintain the protection of the senior securities. ${ }^{90}$ A more serious problem is raised by the tendency to liquidate during times of business depression. Since a preference for cash or highly liquid holdings is characteristic of periods of falling prices, security holders might redeem in large numbers just at the time when security prices were low and the necessary liquidation on the part of the open-end trusts would aggravate the deflation of security prices. ${ }^{100}$ This tendency would

95. New York Stock Exchange Committee on Stock List, Statement on Investment Trusts (1931). \$2 of c. 14 of the rules adopted by the Governing Committec of the New York stock exchange was amended on May 7,1931 , to read: "No member or firm registered on the exchange shall be associated with an investment trust, whether management, restricted management or fixed type, either by participating in its organization or management or by offering or distributing its securities, unless the Committee on Stock List shall have previously determined that it has no objection to such association and shall not have changed such determination."

96. Shaviro, loc. cit. supra note 18.

97. 49 Stat. 1669 (1936), 26 U. S. C. $\$ 48$ (Supp. 1936); 49 Srat. 1655 (1936), 26 U. S. C. A. $\S 13$ (Supp. 1936). Under these provisions, if a mutual investment trust passes on to its stockholders the net income received, including net capital gains from the sale of securities, it is relieved from the regular corporation and surplus tax. This is accomplished by permitting such a company to deduct the total dividends received by it in computing its net income instead of the usual $85 \%$ of the dividends received.

98. A plan for mutualization of National Investors Corporation has been presented to stockholders. N. Y. Times, Dec. 16, 1936, p. 41, col. 6.

99. Shaviro, loc. cit. supra note 18.

100. This would be similar to the withdrawal of savings deposits during a serious depression. See Statistical Abstract of the United States (Dep't of Commerce 1936) 252. 
make it impossible for trusts to practice the frequently asserted policy of investment of purchasing securities when prices were low. ${ }^{101}$

Some of the proposed regulation of investment trusts is aimed at minimizing the chance of failure rather than at the enforcement of the fiduciary duty of managers. Regulation of this type, similar to tiat imposed upon savings banks and insurance companies, ${ }^{102}$ would attempt to codify certain standard practices of conservative management. For example, it would limit the power of the trust to borrow money ${ }^{103}$ and to speculate, ${ }^{108}$ and would limit the compensation of managers. ${ }^{105}$ It would require a certain amount of diversification of investments by establishing a maximum percent of the stock in a single company that an investment trust could hold and by fixing the maximum percentage of assets of the investment trust that could be invested in any one company. ${ }^{100}$

Further regulation might also prohibit the participation by investment trusts in the underwriting of security issues in order to avoid the risk involved. If such participation were prohibited, it would be the third time in thirty years that underwriting privileges have been denied to financial institutions. Insurance companies were prohibited from underwriting in 1909,107 and commercial banks, through divorce of investment affiliates, in 1933.10s While in each case the primary reason for segregation was the great risk which underwriting involved for a financial institution engaged in handling the funds of investors, there was also the secondary reason of the possibility of abuse, ${ }^{103}$ and on each occasion the abuses vere brought about largely because of the lack of disclosure. ${ }^{110}$

While investment trusts are too new to have a single accepted place in the financial system, it seems clear from the experience of England and America that they can only be considered as a sound media for investment when they are conservatively managed. It is merely superficially inconsistent to permit an individual to speculate with his own money, and at the same time to limit his right to entrust his funds to the discretion of others for

101. Robinson, op. cit. supra note 3 , at 258 .

102. See, for example, limitations placed upon the investments of life insurance companies. N. Y. INs. LAw $\$ 100$ and those placed upon the investments of savings banks, N. Y. Banking Law $\$ 239$.

103. Shaviro, loc. cit. supra note 18. See Ronrsson, op. cit. supra note 3, at 163 for the advantages and disadvantages of borrowing by investment trusts.

104. Perhaps by establishing "legal" investments. See note 102, suspro.

105. Shaviro, loc. cit. sufra, note 18.

106. In order to qualify as a mutual investment trust under the Revenue Act of 1936, similar diversification is necessary. 49 STAт. 1669 (1936), 26 U. S. C. $\$ 48$ (Supp. 1936).

107. N. Y. INs. Law $\$ 100$.

108. 48 Star. 188 (1933), 12 U. S. C. $\$ 377$ (1934).

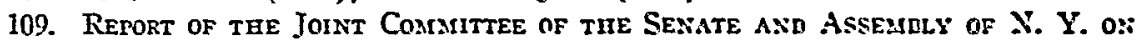
Life Insuraxce Companies (1906) 276; Sen. Rer. op. cit. supro note 23, at 163.

110. Ibid; Westerfield, loc. cit. sulpra note 93. 
the same speculation. It seems accepted in business opinion that investment trusts should be allowed a considerable latitude in their choice of investment policy, so long as that policy is not concealed from prospective purchasers of the trust's securities; but losses have been so severe in several classes of investment trusts that some limitations on managerial discretion appear inevitable.

Legislation to minimize the risk of failure is necessarily restrictive and tends to standardize. ${ }^{111}$ The imposition of such standards upon investment trusts is difficult because so far, at least, investment trusts have been as varied as the ingenuity of their sponsors. Some are formed for the purpose of taking highly speculative risks in the hope of large returns; others are conservative. It is impossible to mold them into one type of institution without destroying their ability to operate for diverse purposes. Investment trusts resemble savings banks and insurance companies for the purposes of restrictive legislation only when control and ownership are divorced. Where the contributors of capital can direct the clestiny of the trust, it is similar to a joint enterprise and should not be restricted as to purpose, whether it be to speculate wildly or to invest conservatively. Furthermore, to restrict the freedom of management gives rise to the same inflexibility and inability to meet continually changing conditions that is the inherent weakness of fixed investment trusts.

To summarize briefly, the first problem in framing further legislation is to determine the effectiveness of disclosure as a remedy for the abuses of investment trusts. By assuming that investors have become more cautious since the halcyon days of 1929 and are aware of the dangers inherent in allowing the control of investment trusts to fall into the hands of those who do not have a substantial pecuniary interest, and by assuming that publicity will deter management from breaching their fiduciary duty, disclosure would seem to be sufficient regulation. If, through experience, such assumptions prove incorrect, regulation of the capital structures of newly formed trusts appears necessary for the purpose of preventing contributors of capital from being deprived of control; and in the case of trusts already formed, where such deprivation of control exists, regulation to enforce fiduciary duty by prohibiting managers from dealing with the trust either directly or indirectly seems desirable. To go further and attempt directly to minimize the chance of failure by fixing standards for all trusts would not only restrict the use of investment trusts, but would give investors the misleading impression that regulation leads inevitably to successful operation - which in the last analysis depends upon honest and competent management acting with the incentive furnished by a substantial stake in the enterprise.

111. RoBInson, op. cit. supra note 3, at 286. 